\title{
Risks associated with a double-cropping production system - a case study in southern
}

\author{
Brazil \\ Mauro Osaki*®, Lucilio Rogerio Aparecido Alves $\odot$, Fabio Francisco Lima๑, Renato Garcia Ribeiro॰ ${ }^{*}$ Geraldo Sant'Ana de Camargo \\ Barros ${ }^{\circledR}$
}

Universidade de São Paulo/ESALQ/Centro de Estudos Avançados em Economia Aplicada - Depto. de Economia, Administração e Sociologia, Av. Pádua Dias, 11 - 13418900 - Piracicaba, SP - Brasil.

*Corresponding author <mosaki@usp.br>

Edited by: Lincoln Zotarelli

Received May 27, 2017

Accepted December 06, 2017
ABSTRACT: This study assessed the risk exposure of the production system of a typical farm in southern Brazil. Five possible production systems were analyzed, combining three crops (soybeans, corn seasons and wheat) in different crop-year combinations, for example: "Summer soybeans followed by corn" and "Autumn corn followed by winter wheat". Five different production systems were created based on the intensity of land use for each of the crops. Primary data were collected from a typical farm in the producing region over eight seasons (2006/07 to 2013/14). The Monte Carlo simulation technique was used to evaluate negative Net Operating Revenue (NOR) risk. The results showed that the production system with soybean and first season corn had a higher NOR and lower risk when compared with the other four production systems, which intensified the land use in the second season. When the production system had a higher rate of corn and/or wheat, the NOR and the risk to the production system increased for the first or second crop. Both corn and wheat in the second crop increased the risk to the production system on the typical farm in Cascavel, in the state of Parana (PR).

Keywords: Monte Carlo simulation, risk analysis, farm risk

\section{Introduction}

Agricultural production is subject to considerable market risks. These risks have been exacerbated by the onward march of climate change and globalization. One of the main concerns of agricultural policy makers has been to provide support to rural producers in the area of risk management.

The contribution of this study was aimed at assessing the risks farmers are subject to by analysing production variability and market conditions, using a typical farm as the study object, that is, not only the individual crops, as is usual, but the set of activities developed at the farm. Therefore, when assessing the risks, the allocative decisions taken by the producers were considered in order to manage them.

A number of the risk assessments in different agricultural production systems, using the Monte Carlo simulation method, have been examined in papers by authors such as Ponciano et al. (2004), Arêdes et al. (2007), Melo et al. (2012) and Asci et al. (2014). It was observed that several of the published studies have, in the main, assessed the risk of the activity referencing only one crop year, neglecting the time of purchase of inputs and sale of each crop production, as well as successive crops, which impact decisions on the use of varieties, fertilizers and other inputs. A further observation is that the studies limit the risk assessment of the agricultural product, and ignore the production systems on a typical farm, that is, summer crops and second season crops, an arrangement typically found in Brazil.

Thus, our study attempted to fill this gap in order to assess the risk of different agricultural production systems on a small farm. The data are derived from primary data collected over eight seasons (2006/07 to 2013/14), provided by the Center for Advanced Studies on Applied Economics (CEPEA, 2016). The assessment focused on the five possible production systems available to the farm, combining four agricultural products (soybean, corn, second crop corn and wheat), as related to the six different forms of land use for the first and second crop. To assess the risk of the various production systems, the Monte Carlo simulation technique was used.

\section{Materials and Methods}

\section{Data source and processing}

The data used in this study were obtained from CEPEA (2016). According to the Center, the primary data were collected on a typical farm in the Cascavel region (PR), $\left(24^{\circ} 57^{\prime} 21^{\prime \prime} \mathrm{S} 53^{\circ} 27^{\prime} 18^{\prime \prime} \mathrm{W}\right), 780 \mathrm{~m}$ above sea level, at the end of each crop year from the 2006/07 to the $2013 / 14$ crop. The frame of reference is a typical farm in the region, with a theoretical basis for definition, characterization and location choice criterion from the scientific works of the following authors: Elliott (1928), Plaxico and Tweeten (1963), Hazell and Norton (1986), Feuz and Skold (1991) and Deblitz et al. (1998). The panel-data collection moderation was based on the material proposed by Deblitz et al. (1998). The typical farm criterion and data collection were used in the study of Osaki and Batalha (2014).

The study was carried out using the data from a typical farm in the region of Cascavel (PR), which, since the 1990's, has recorded significant changes in the production system. During that time, farmers have selected soybean and corn (summer) as the first crop 
and wheat as the second crop (autumn/winter) for their agricultural areas. With the introduction of new short and medium-cycle soybean cultivars and the prevalence of direct sowing (agricultural implements, agricultural pesticides and fertility management), producers in Paraná now have an apparently lower risk alternative in the second crop when it is corn rather than wheat and, in particular, greater marketing liquidity, which may result in higherNOR.

According to CEPEA (2016), the data used in this work were obtained through primary surveys conducted during the second and third quarter from 2007 to 2014. The size of the typical farm in the region of Cascavel (PR) was 65 hectares, with the area sown with soybean in summer and the second crop with corn and wheat. These activities are carried out by three tractors and a grain harvester. The employees consist of two tractor drivers, a temporary worker (seasonal worker) and two family members. The physical structure was the same for the eight seasons assessed (2006/07 to 2013/14) and the average monetary values of each crop were adjusted with reference to the IGP-DI /General Price Index Internal Availability), using Dec 2014 as a base (IPEA, 2015).

The primary data collected over eight seasons were treated statistically, defining the probability function and generating 5,000 interactions for each of the main items that comprise the operating cost consisting of: fertilizers, treated seeds, herbicides, insecticides, fungicides, other inputs (adjuvants and spreader-stickers), mechanical operation, outsourced services, manual labor, general farm and miscellaneous expenses (sales tax, technical support, insurance and interest on working capital), yield, price to arrive at net operating revenues.

The crops available at the farm generate five different production systems. As the land-use intensity changes every crop year, the farm's cost and income effects were simulated at six different land-use intensities in the first and second crop (Table 1). Production System 1 (System 1) consists of the combination of soybean and corn in the first crop with no second crop cultivated. The system begins with soybean cultivation in $100 \%$ of the area, followed by the combination of $80 \%$ soybean and $20 \%$ corn; $60 \%$ and $40 \% ; 40 \%$ and $60 \% ; 20 \%$ and $80 \%$ and ends with $100 \%$ corn.

Keeping the same land-use systematization of System 1, which only considered first crop cultivations (summer), the other four systems were structured so as to analyze the inclusion of the second crop with only corn, then only wheat and finally, with both crops. System 2 analyzed the distribution of the second crop between corn and wheat; System 3 analyzed the use of corn only in the second crop, with different land-use intensity; in System $4100 \%$ of the area of the second crop was sown with corn; in System $5100 \%$ of the area of second crop was sown with wheat.

\section{Conceptual model}

Based on the technical coefficients and input purchase prices, the production operating costs for each crop were calculated in each crop year and

Table 1 - Land use for different productions systems with the combination of first and second crop in the typical farm in Cascavel.

\begin{tabular}{|c|c|c|c|c|c|c|c|c|}
\hline \multirow{2}{*}{ Systems } & \multirow{2}{*}{ Crop-year } & \multirow{2}{*}{ Crop } & \multicolumn{6}{|c|}{ Land use } \\
\hline & & & Type 1 & Type 2 & Type 3 & Type 4 & Type 5 & Type 6 \\
\hline & & & & & & 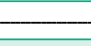 & & \\
\hline \multirow{4}{*}{ System 1} & \multirow{2}{*}{$1^{\text {st }}$} & Soybean & 100 & 80 & 60 & 40 & 20 & 0 \\
\hline & & Corn first crop & 0 & 20 & 40 & 60 & 80 & 100 \\
\hline & \multirow{2}{*}{$2^{\text {nd }}$} & Corn second crop & 0 & 0 & 0 & 0 & 0 & 0 \\
\hline & & Wheat & 0 & 0 & 0 & 0 & 0 & 0 \\
\hline \multirow{4}{*}{ System 2} & \multirow{2}{*}{$1^{\text {st }}$} & Soybean & 100 & 80 & 60 & 40 & 20 & 0 \\
\hline & & Corn first crop & 0 & 20 & 40 & 60 & 80 & 100 \\
\hline & \multirow{2}{*}{$2^{\text {nd }}$} & Corn second crop & 100 & 80 & 60 & 40 & 20 & 0 \\
\hline & & Wheat & 0 & 20 & 40 & 60 & 80 & 100 \\
\hline \multirow{4}{*}{ System 3} & \multirow{2}{*}{$1^{\text {st }}$} & Soybean & 100 & 80 & 60 & 40 & 20 & 0 \\
\hline & & Corn first crop & 0 & 20 & 40 & 60 & 80 & 100 \\
\hline & \multirow{2}{*}{$2^{\text {nd }}$} & Corn second crop & 100 & 80 & 60 & 40 & 20 & 0 \\
\hline & & Wheat & 0 & 0 & 0 & 0 & 0 & 0 \\
\hline \multirow{4}{*}{ System 4} & \multirow{2}{*}{$1^{\text {st }}$} & Soybean & 100 & 80 & 60 & 40 & 20 & 0 \\
\hline & & Corn first crop & 0 & 20 & 40 & 60 & 80 & 100 \\
\hline & \multirow{2}{*}{$2^{\text {nd }}$} & Corn second crop & 100 & 100 & 100 & 100 & 100 & 100 \\
\hline & & Wheat & 0 & 0 & 0 & 0 & 0 & 0 \\
\hline \multirow{4}{*}{ System 5} & \multirow{2}{*}{$1^{\text {st }}$} & Soybean & 100 & 80 & 60 & 40 & 20 & 0 \\
\hline & & Corn first crop & 0 & 20 & 40 & 60 & 80 & 100 \\
\hline & \multirow{2}{*}{$2^{\text {nd }}$} & Corn second crop & 0 & 0 & 0 & 0 & 0 & 0 \\
\hline & & Wheat & 100 & 100 & 100 & 100 & 100 & 100 \\
\hline
\end{tabular}

Source: Research data. 
were then compared to Gross Revenue, which was obtained by multiplying the production volume by the price of each product. Therefore, in this study the conceptual model estimated the economic indicators founded on the climatic and economic risks of the activity in each crop year. Based on the historical evolution of each operating cost and revenue item, the distribution functions of each item were obtained. Conceptually, based on aggregate data, we have:

$$
N O R_{i}=\sum_{i=1}^{n} G R_{i}-O C_{i} \quad(1, \ldots, n)
$$

Being: $N O R_{i}=f\left(N O R_{i}\right)$ : Cumulative probability distribution of the net operating revenue of the $i$ th product used in the production system; $G R_{i}=f\left(G R_{i}\right)$ : Cumulative probability distribution of the gross revenue of the ith product used in the production system; $O C_{i}$ $=f\left(O C_{i}\right)$ : Cumulative probability distribution of the operating cost of the ith product used in the production system; $n$ : number of data simulated.

The definitions of the economic indicators assessed in the study are as follows: a) Operating Cost (OC) is the sum of the amounts spent during the production process, consisting of fertilizers, treated seeds, herbicides, fungicides, other inputs (adjuvants and spreader-stickers), mechanical operations, outsourced services, manual labor, general expenses of the farm and miscellaneous, sales tax, technical assistance, insurance and interest on working capital; b) Gross Revenue (GR) is the sum of the agricultural product values negotiated by the farm during the season under assessment; c) Net Operating Revenue (NOR) is the difference between gross revenue and operating cost.

\section{Monte Carlo Method}

The Monte Carlo method was originally developed by Hertz (1964) and later by financial experts. The process consists of defining the relative frequency of occurrence of a certain phenomenon under analysis, defining the distribution function that best suits the relative frequency, and randomly repeating the experiment several times within the established limits (Hertz, 1964). Thus, the objective of the Monte Carlo method is to determine alternative economic situations by projecting values which are random but within the limit imposed by the distribution of the variables (Hertz, 1964).

Noronha (1987) suggests a sequence of calculations to conduct the Monte Carlo simulation:

I. Identify the probability distribution of each of the variables relevant to the study;

II. Randomly select a value for each variable from its probability distribution;

III. Calculate the value of the selected indicator each time the random drawing is made as indicated in item II;
IV. Repeat the process until an appropriate confirmation of the frequency distribution of the selected indicator is obtained. This distribution will serve as the basis for decision-making.

The Monte Carlo method is simple and is often utilized in many research studies. However, two problems should be emphasized. The first refers to the definition stage of the probability distribution, and the second to the acquisition of random values.

The first problem focuses on the difficulty of determining algebraically the distribution function of the items of greatest relevance in the scope of the study. Therefore, so as to circumnavigate the problem, many studies treat the price distributions as a proxy, as in the case of a normal distribution, which is based on the large numbers theorem. Studies such as Ponciano et al. (2004), assumed a triangular distribution, with the functions defined by the most probable average level or modal, minimum and maximum level, which is important when insufficient prior knowledge is available about the variables. The second problem was that, even though the numbers are generated randomly in the predetermined distribution limit, the difficulty lies in finding the interdependence relationship between the variables, since the covariance of certain of the products is not zero.

For Blank and Tarquin (2012), the Monte Carlo simulation was regarded as a substitute method of a study of a non-stochastic process by a probabilistic model. In this context, the deterministic problems can be assessed by a series of random samplings.

Specifically in this study, the following variables were considered as risk factors in the production cost: fertilizers, treated seeds, herbicides, insecticides, fungicides, other inputs (adjuvants and spreaderstickers), mechanical operation, outsourced services, manual labor, general and miscellaneous expenses of the farm (sales tax, technical assistance, insurance and interest on working capital), yield, price and net operating revenues.

Based on the frequency distribution of the original data, the model calculates mean and standard deviation and analyzes, for each item in the production, cost structure and revenue, and the frequency distribution that best fits. This selection is made based on the Akaike test. From the choice of distribution, the model generates 5,000 random observations, as per the Monte Carlo simulation. In the generation of random numbers, the correlation matrix between the variables with distribution functions was structured, that is, for each variable in the crops, subjected to analysis.

Next, using the Monte Carlo Method, 5,000 random interactions were simulated for each variable of each production system. All risk analysis procedures were carried out using the @risk software program, version 6. The outputs in Operating Cost (OC), Gross Revenue (GR) and Net Operating Revenue (NOR) were also generated in these interactions. 


\section{Results and Discussion}

The results discussed in this section can be divided into two subsections. The first subsection organized the statistical description of the data series used in the study. The second exhibits the risks in the production systems of the typical farm.
Descriptive statistics of the economic indicators

Table 2 illustrates the estimated frequency distribution functions for the risk variables that comprise the production cost and gross revenue of the typical farm in Cascavel (PR). The production cost is arranged by fertilizer, treated seeds, herbicides, insecticides, fungicides, others inputs, mechanical operation, service, labor cost,

Table 2 - Probability distribution of each variable which determined production cost and gross revenue of the typical farm in Cascavel (PR), 5000 random data, in US\$ ha-1.

\begin{tabular}{|c|c|c|c|c|c|c|}
\hline \multicolumn{7}{|c|}{ Soybean } \\
\hline Variable & Distribution & Average & Mode & Median & SD & $\mathrm{CV}$ \\
\hline & & & & & & $\%$ \\
\hline Fertilizer & Extreme value & 148.86 & 132.61 & 142.93 & 36.11 & 24.25 \\
\hline Seeds treated & Extreme value & 83.40 & 76.81 & 80.99 & 14.63 & 17.55 \\
\hline Herbicides & Normal & 42.23 & 41.82 & 42.01 & 17.04 & 40.34 \\
\hline Insecticides & Extreme value & 37.22 & 32.67 & 35.56 & 10.11 & 27.18 \\
\hline Fungicides & Normal & 49.28 & 49.28 & 49.28 & 7.52 & 15.26 \\
\hline Others inputs & Minimum extreme value & 15.93 & 18.39 & 16.60 & 6.10 & 38.27 \\
\hline Mechanical Operation & Minimum extreme value & 90.80 & 101.36 & 94.44 & 23.46 & 25.84 \\
\hline Service & Extreme value & 31.75 & 24.88 & 29.24 & 15.24 & 47.99 \\
\hline Labor cost & Extreme value & 60.20 & 47.97 & 55.74 & 27.15 & 45.10 \\
\hline Farm overhead & Extreme value & 42.44 & 35.38 & 39.86 & 15.69 & 36.97 \\
\hline Other (miscellaneous) & Extreme value & 88.01 & 92.02 & 89.47 & 8.90 & 10.11 \\
\hline Yield $\left(\mathrm{t} \mathrm{ha}^{-1}\right)$ & Minimum extreme value & 1.20 & 1.28 & 1.23 & 0.18 & 15.36 \\
\hline Price (US\$ $\left.t^{-1}\right)$ & Minimum extreme value & 354.53 & 372.94 & 361.01 & 40.93 & 11.54 \\
\hline Gross Revenue & Output & 1067.05 & 1119.84 & 1088.93 & 199.95 & 18.74 \\
\hline Operating Cost & Output & 690.13 & 690.18 & 688.53 & 51.04 & 7.40 \\
\hline Net Operating Revenue & Output & 376.93 & 531.48 & 402.27 & 192.03 & 50.95 \\
\hline Prob. NOR $<0$ & & $4.0 \%$ & & & & \\
\hline \multicolumn{7}{|l|}{ Corn first crop } \\
\hline Fertilizer & Extreme value & 332.19 & 307.02 & 321.65 & 64.13 & 19.30 \\
\hline Seeds treated & Minimum extreme value & 203.59 & 219.21 & 210.37 & 41.94 & 20.60 \\
\hline Herbicides & Minimum extreme value & 42.58 & 45.44 & 43.71 & 6.92 & 16.24 \\
\hline Insecticides & Normal & 17.99 & 17.25 & 17.78 & 8.10 & 45.02 \\
\hline Fungicides & Normal & 16.58 & 13.55 & 15.90 & 9.25 & 55.78 \\
\hline Other inputs & Extreme value & 6.15 & 4.07 & 5.23 & 5.61 & 91.20 \\
\hline Mechanical Operation & Minimum extreme value & 95.28 & 102.60 & 98.82 & 22.31 & 23.41 \\
\hline Service & Extreme value & 92.51 & 78.05 & 87.05 & 33.26 & 35.96 \\
\hline Labor cost & Minimum extreme value & 57.63 & 67.08 & 60.13 & 20.79 & 36.08 \\
\hline Farm overhead & Extreme value & 42.44 & 35.29 & 39.86 & 15.69 & 36.97 \\
\hline Other (miscellaneous) & Minimum extreme value & 109.49 & 113.21 & 110.89 & 8.55 & 7.81 \\
\hline Yield $\left(\mathrm{t} \mathrm{ha}^{-1}\right)$ & Minimum extreme value & 3.73 & 3.88 & 3.79 & 0.40 & 10.69 \\
\hline Price (US\$ $\left.t^{-1}\right)$ & Normal & 157.79 & 157.53 & 157.79 & 20.90 & 13.24 \\
\hline Gross Revenue & Output & 1482.53 & 1518.83 & 1486.30 & 264.57 & 17.85 \\
\hline Operating Cost & Output & 1016.42 & 985.49 & 1016.07 & 81.35 & 8.00 \\
\hline Net Operating Revenue & Output & 466.11 & 543.05 & 471.04 & 299.52 & 64.26 \\
\hline Prob. NOR $<0$ & & $6.3 \%$ & & & & \\
\hline \multicolumn{7}{|l|}{ Corn second crop } \\
\hline Fertilizer & Minimum extreme value & 208.01 & 232.24 & 216.35 & 53.81 & 25.87 \\
\hline Seeds treated & Minimum extreme value & 166.28 & 185.03 & 172.79 & 41.60 & 25.02 \\
\hline Herbicides & Normal & 33.61 & 33.60 & 33.60 & 9.78 & 29.10 \\
\hline Insecticides & Normal & 20.50 & 20.50 & 20.50 & 5.83 & 28.46 \\
\hline Fungicides & Minimum extreme value & 21.56 & 24.78 & 22.50 & 7.65 & 35.47 \\
\hline Other inputs & Extreme value & 1.09 & 0.44 & 0.90 & 0.87 & 79.78 \\
\hline
\end{tabular}


Table 2 - Continuation.

\begin{tabular}{|c|c|c|c|c|c|c|}
\hline Mechanical Operation & Minimum extreme value & 83.48 & 93.16 & 86.81 & 21.49 & 25.75 \\
\hline Service & Extreme value & 54.04 & 47.83 & 51.77 & 13.80 & 25.54 \\
\hline Labor cost & Minimum extreme value & 48.68 & 55.84 & 50.83 & 16.71 & 34.32 \\
\hline Farm overhead & Extreme value & 42.44 & 35.38 & 39.86 & 15.69 & 36.96 \\
\hline Other (miscellaneous) & Minimum extreme value & 74.11 & 78.65 & 75.77 & 10.08 & 13.60 \\
\hline Yield (t ha-1) & Normal & 1.90 & 1.91 & 1.90 & 0.26 & 13.80 \\
\hline Price (US\$ $t^{-1}$ ) & Extreme value & 151.07 & 138.33 & 146.42 & 28.32 & 18.74 \\
\hline Gross Revenue & Output & 719.16 & 671.23 & 701.10 & 149.65 & 20.81 \\
\hline Operating Cost & Output & 753.82 & 781.07 & 757.62 & 95.26 & 12.64 \\
\hline Net Operating Revenue & Output & -34.65 & -96.40 & -53.58 & 164.52 & -474.78 \\
\hline Prob. NOR $<0$ & & $63.10 \%$ & & & & \\
\hline \multicolumn{7}{|c|}{ Wheat } \\
\hline \multirow[t]{2}{*}{ Variable } & Distribution & Average & Mode & Median & SD & $\mathrm{CV}$ \\
\hline & & & & & & $\%$ \\
\hline Fertilizer & Extreme value & 164.79 & 154.16 & 161.13 & 22.30 & 13.53 \\
\hline Seeds treated & Normal & 104.22 & 102.13 & 104.22 & 23.78 & 22.82 \\
\hline Herbicides & Normal & 29.98 & 30.30 & 29.85 & 11.80 & 39.36 \\
\hline Insecticides & Minimum extreme value & 10.93 & 12.43 & 11.40 & 3.95 & 36.11 \\
\hline Fungicides & Minimum extreme value & 30.58 & 34.19 & 31.92 & 10.77 & 35.21 \\
\hline Other inputs & Normal & 2.85 & 2.94 & 2.83 & 1.21 & 42.53 \\
\hline Mechanical Operation & Normal & 63.66 & 64.93 & 63.20 & 26.86 & 42.20 \\
\hline Service & Extreme value & 20.40 & 15.41 & 18.82 & 9.59 & 47.02 \\
\hline Labor cost & Minimum extreme value & 41.80 & 46.99 & 43.61 & 12.52 & 29.96 \\
\hline Farm overhead & Extreme value & 42.44 & 36.28 & 39.86 & 15.68 & 36.95 \\
\hline Other (miscellaneous) & Extreme value & 51.65 & 47.56 & 50.11 & 9.42 & 18.23 \\
\hline Yield $\left(\mathrm{t} \mathrm{ha}^{-1}\right)$ & Extreme value & 0.85 & 0.76 & 0.82 & 0.22 & $26.2 \varepsilon$ \\
\hline Price (US\$ $t^{-1}$ ) & Extreme value & 228.00 & 199.53 & 217.24 & 65.46 & 28.71 \\
\hline Gross Revenue & Output & 480.68 & 464.83 & 456.28 & 158.78 & 33.03 \\
\hline Operating Cost & Output & 563.31 & 560.75 & 560.16 & 61.49 & 10.92 \\
\hline Net Operating Revenue & Output & -82.63 & -176.14 & -102.87 & 121.40 & -146.92 \\
\hline Prob. NOR $<0$ & & $80.0 \%$ & & & & \\
\hline
\end{tabular}

farm overhead and other miscellaneous items. As for gross revenue it was determined by the yield and the price of the three crops found on the typical Cascavel farm. It also shows the average, mode, median, standard deviation and coefficient of variation for each variable after 5,000 random interactions, in terms of the mean value of eight seasons (2006/07 to 2013/14) adjusted data for Dec/2014.

Generally, the same distribution functions prevailed in the crops analyzed. For the same production cost item, equality of distribution was also commonly observed, regardless of the crop analyzed. The functions identified were: Extreme Value, Minimum Extreme and Normal Value.

In Table 2, the average NOR of soybean was US\$ $376.9 \mathrm{ha}^{-1}$ and prob. NOR $<0$ was $4 \%$. The first corn crop had an average NOR of US\$ $466.1 \mathrm{ha}^{-1}$ and the prob. NOR < 0 was $6 \%$; the second corn crop had a negative NOR of US\$34.6 ha ${ }^{-1}$ and prob. NOR $<0$ was $63 \%$ and for wheat the negative NOR was US $\$ 82.6 \mathrm{ha}^{-1}$ and prob. NOR $<0$ was $80 \%$.
Interestingly, the different factors that make up the cost of production and the gross revenue also influence the variation in profitability of the production system of a typical farm. Thus, sensitivity analysis helps to identify the critical variables that may be the risk factor in the agricultural production of soybeans, corn and wheat.

Next, using as a reference the productive systems of the typical farm described in Table 1, the costs and revenues of the productive systems were calculated in terms of output. The subtraction of the Operating Cost from Gross Revenue generated the NOR of each system, which also randomly generated the 5,000 interactions. Table 3 illustrates the descriptive statistical information of the NOR of each system, according to the proposed land use. In general, the high coefficient of variation (CV) values show the expressive dispersion of the NOR in the systems analyzed. Further details of the negative NOR risks are presented in the following section. 
Table 3 - Frequency distribution of Net Operating Revenue (NOR) of five productions systems simulated on a typical farm in Cascavel (PR), with different land-use intensities, in US\$ ha ${ }^{-1}$ or percentage.

\begin{tabular}{|c|c|c|c|c|c|c|c|}
\hline \multicolumn{8}{|c|}{ System 1 (no double-crop) } \\
\hline & $1^{\text {st }}$ Crop (S - M1) & $100-0$ & $80-20$ & $60-40$ & $40-60$ & $20-80$ & $0-100$ \\
\hline & $2^{\text {nd }}$ Crop (M2 - W) & $0-0$ & $0-0$ & $0-0$ & $0-0$ & $0-0$ & $0-0$ \\
\hline GR & Average & 1067.05 & 1150.15 & 1233.24 & 1316.34 & 1399.44 & 1482.53 \\
\hline $\mathrm{OC}$ & Average & 690.13 & 755.38 & 820.64 & 885.90 & 951.16 & 1016.42 \\
\hline \multirow{8}{*}{ NOR } & Minimum & -666.55 & -563.01 & -459.47 & -355.93 & -616.15 & -877.45 \\
\hline & Maximum & 848.03 & 859.29 & 931.85 & 1121.66 & 1311.47 & 1561.17 \\
\hline & Average & 376.93 & 394.76 & 412.60 & 430.44 & 448.27 & 466.11 \\
\hline & Standard deviation & 191.99 & 163.93 & 164.81 & 194.25 & 242.04 & 299.52 \\
\hline & Variance & 92742.13 & 67609.74 & 68340.22 & 94933.62 & 147389.86 & 225709.02 \\
\hline & Mode & 447.21 & 419.47 & 403.16 & 457.14 & 417.76 & 543.05 \\
\hline & CV (\%) & 50.94 & 41.53 & 39.94 & 45.13 & 53.99 & 64.26 \\
\hline & Prob. NOR < $0(\%)$ & 4.00 & 2.10 & 1.40 & 1.80 & 3.50 & 6.30 \\
\hline \multicolumn{8}{|c|}{ System 2 (second corn and wheat 0 - 100) } \\
\hline & $1^{\text {st }}$ Crop (S - M1) & $100-0$ & $80-20$ & $60-40$ & $40-60$ & $20-80$ & $0-100$ \\
\hline & $2^{\text {nd }}$ Crop (M2 - W) & $100-0$ & $80-20$ & $60-40$ & $40-60$ & $20-80$ & $0-100$ \\
\hline GR & Average & 1786.22 & 1821.62 & 1857.01 & 1892.41 & 1927.81 & 1963.21 \\
\hline $\mathrm{OC}$ & Average & 1443.94 & 1471.10 & 1498.26 & 1525.42 & 1552.57 & 1579.73 \\
\hline \multirow[t]{8}{*}{ NOR } & Minimum & -785.21 & -614.22 & -450.83 & -440.24 & -746.51 & -1052.77 \\
\hline & Maximum & 1518.01 & 1264.09 & 1165.49 & 1349.64 & 1533.79 & 1717.94 \\
\hline & Average & 342.28 & 350.52 & 358.76 & 367.00 & 375.24 & 383.48 \\
\hline & Standard deviation & 251.39 & 211.63 & 199.45 & 219.50 & 264.55 & 324.34 \\
\hline & Variance & 159008.15 & 112680.92 & 100084.38 & 121218.52 & 176083.39 & 264678.93 \\
\hline & Mode & 296.32 & 339.04 & 430.68 & 348.61 & 313.69 & 411.34 \\
\hline & CV (\%) & 73.45 & 60.38 & 55.59 & 59.81 & 70.50 & 84.58 \\
\hline & Prob. NOR < $0(\%)$ & 8.40 & 5.10 & 3.70 & 4.80 & 7.60 & 11.90 \\
\hline \multicolumn{8}{|c|}{ System 3 (Second corn 0-100) } \\
\hline & $1^{\text {st }}$ Crop (S - M1) & $100-0$ & $80-20$ & $60-40$ & $40-60$ & $20-80$ & $0-100$ \\
\hline & $2^{\text {nd }}$ Crop (M2 - W) & $100-0$ & $80-0$ & $60-0$ & $40-0$ & $20-0$ & $0-0$ \\
\hline GR & Average & 1786.22 & 1725.48 & 1664.74 & 1604.01 & 1543.27 & 1482.53 \\
\hline $\mathrm{OC}$ & Average & 1443.94 & 1358.44 & 1272.93 & 1187.43 & 1101.93 & 1016.42 \\
\hline \multirow[t]{11}{*}{ NOR } & Minimum & -785.21 & -577.31 & -369.40 & -335.05 & -606.25 & -877.45 \\
\hline & Maximum & 1518.01 & 1287.65 & 1194.69 & 1119.70 & 1310.49 & 1561.17 \\
\hline & Average & 342.28 & 367.04 & 391.81 & 416.58 & 441.34 & 466.11 \\
\hline & Standard deviation & 251.39 & 210.24 & 193.27 & 206.53 & 245.17 & 299.52 \\
\hline & Variance & 159008.15 & 111207.27 & 93976.95 & 107317.09 & 151227.82 & 225709.02 \\
\hline & Mode & 296.32 & 338.27 & 362.77 & 447.94 & 509.65 & 543.05 \\
\hline & CV (\%) & 73.45 & 57.28 & 49.33 & 49.58 & 55.55 & 64.26 \\
\hline & Prob. NOR < $0(\%)$ & 8.40 & 4.40 & 2.70 & 2.50 & 4.00 & 6.30 \\
\hline & \multicolumn{6}{|c|}{ System 4 (100 \% second corn) } & \\
\hline & $1^{\text {st }}$ Crop (S - M1) & $100-0$ & $80-20$ & $60-40$ & $40-60$ & $20-80$ & $0-100$ \\
\hline & $2^{\text {nd }}$ Crop (M2 - W) & $100-0$ & $100-0$ & $100-0$ & $100-0$ & $100-0$ & $100-0$ \\
\hline GR & Average & 1786.22 & 1869.31 & 1952.41 & 2035.50 & 2118.60 & 2201.70 \\
\hline $\mathrm{OC}$ & Average & 990.07 & 1092.49 & 1186.67 & 1224.21 & 1237.19 & 1250.18 \\
\hline \multirow[t]{8}{*}{ NOR } & Minimum & -785.21 & -637.79 & -490.36 & -457.41 & -566.64 & -827.93 \\
\hline & Maximum & 1518.01 & 1444.09 & 1417.25 & 1440.71 & 1464.17 & 1553.71 \\
\hline & Average & 342.28 & 360.11 & 377.95 & 395.79 & 413.62 & 431.46 \\
\hline & Standard deviation & 251.39 & 232.26 & 234.46 & 257.44 & 296.41 & 346.01 \\
\hline & Variance & 159008.15 & 135726.23 & 138307.23 & 166751.11 & 221057.87 & 301227.46 \\
\hline & Mode & 296.32 & 322.43 & 324.29 & 366.16 & 479.72 & 520.61 \\
\hline & CV (\%) & 73.45 & 64.50 & 62.03 & 65.05 & 71.66 & 80.20 \\
\hline & Prob. NOR< 0 (\%) & 8.40 & 6.00 & 4.90 & 5.70 & 8.10 & 10.40 \\
\hline
\end{tabular}

Continue... 
Table 3 - Continuation.

\begin{tabular}{|c|c|c|c|c|c|c|c|}
\hline \multicolumn{8}{|c|}{ System 5 (100 \% Wheat) } \\
\hline & $1^{\text {st }}$ Crop (S - M1) & $100-0$ & $80-20$ & $60-40$ & $40-60$ & $20-80$ & $0-100$ \\
\hline & $2^{\text {nd }}$ Crop (M2 - W) & $0-100$ & $0-100$ & $0-100$ & $0-100$ & $0-100$ & $0-100$ \\
\hline GR & Average & 1547.73 & 1630.83 & 1713.92 & 1797.02 & 1880.11 & 1963.21 \\
\hline OC & Average & 1253.44 & 1318.69 & 1383.95 & 1449.21 & 1514.47 & 1579.73 \\
\hline \multirow[t]{8}{*}{ NOR } & Minimum & -880.38 & -776.84 & -673.30 & -569.76 & -791.48 & -1052.77 \\
\hline & Maximum & 1177.83 & 1285.85 & 1393.88 & 1501.90 & 1609.92 & 1717.94 \\
\hline & Average & 294.29 & 312.13 & 329.97 & 347.80 & 365.64 & 383.48 \\
\hline & Standard deviation & 225.26 & 202.67 & 204.18 & 229.30 & 271.57 & 324.34 \\
\hline & Variance & 127671.50 & 103347.22 & 104885.81 & 132287.32 & 185551.67 & 264678.93 \\
\hline & Mode & 396.78 & 353.74 & 375.04 & 319.49 & 327.17 & 411.34 \\
\hline & CV (\%) & 76.54 & 64.93 & 61.88 & 65.93 & 74.27 & 84.58 \\
\hline & Prob. NOR $<0(\%)$ & 9.30 & 6.00 & 5.00 & 6.00 & 8.80 & 11.90 \\
\hline
\end{tabular}

$\mathrm{S}=$ Soybean; M1 = Corn first crop; $\mathrm{M} 2$ = Corn second crop; $\mathrm{W}=$ Wheat; $\mathrm{GR}=$ Gross Revenue; OC = Operating Cost; NOR = Net Operating Revenue; CV = Coefficient of variation; Source: Research data.

\section{Risk of the production system on a typical farm in Cascavel (PR)}

In this section, the results of the economic analysis, including risk, of the five production systems with different land use intensities are presented for the typical farm in Cascavel (PR), according to Figure 1. System 1, which cultivates soybean and summer corn and has no double-crop, showed the highest return and lowest negative net operating return in the representative production systems of the typical farm. The cultivation of the entire area with soybean showed a probability of $4 \%$ of presenting negative NOR. In this case, the agricultural area planted with $80 \%$ soybean and $20 \%$ with corn in the summer period has the potential to register a negative return of $2 \%$. However, as the area sown with corn after soybean increases in System 1, the return and the risk also increase (Figure 1). Dividing the agricultural area into $60 \%$ soybean and $40 \%$ corn in the first crop, a negative return risk of $1 \%$ and average net revenue of US\$ $412.6 \mathrm{ha}^{-1}$ was identified. When the ratio of the soybean area in the agricultural area was reversed to $40 \%$ soybean and $60 \%$ corn, the negative return risk increases to $2 \%$ and the mean operating return is US\$ 430.4 ha-1. With a composition of $80 \%$ corn and 20 $\%$ soybean in the agricultural area in the first crop, the risk of this activity showing a negative result is $3 \%$ and the average operating return US $\$ 448.3 \mathrm{ha}^{-1}$. The maximum risk in the summer cultivation arises when $100 \%$ of the area is planted with corn, which generates an average return of US $\$ 466.1 \mathrm{ha}^{-1}$ and the risk of a negative return rises to an estimated $6 \%$.

By analyzing individually, the two crops frequently grown in the first crop in Cascavel (PR), it is noted that corn presents a higher risk than soybean. The result was contrary to that observed by Melo et al. (2012), who diagnosed greater variability in the net revenue of soybean (higher variance and standard deviation) when compared to corn.

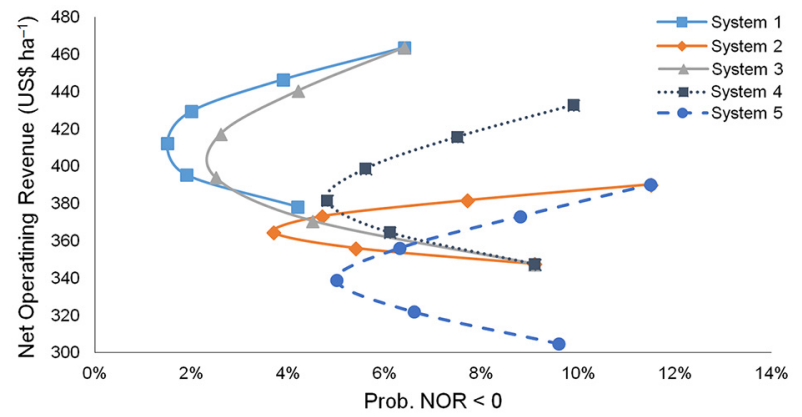

Figure 1 - Economic return (NOR) and probability of a negative return of five production systems of the typical farm in Cascavel (PR), US\$ ha-1. System 1 (S1): soybean and first corn (0 - $100 \%$; System 2: (S1) + second corn and wheat (0 - $100 \%)$; System 3: (S1) + second corn (0 - 100); System 4: (S1) + second corn (100 $\%)$; and System 5: (S1) + wheat (100\%); Source: Research data.

The result shown in Table 3 indicates that corn provides a greater risk to the farm's activity than soybean (higher variance and standard deviation). From the agronomic point of view, corn is more sensitive to thermal variation than soybean. The thermal elevation for each vegetative phase of the crop provokes a different productivity response. In general, corn is more sensitive to nocturnal temperature than soybean, because a small thermal difference between daytime and nighttime temperature causes the plant to continue to release energy during the respiration process. Lobell and Field (2007) apud Hatfield et al. (2011) found that a temperature increase of $1{ }^{\circ} \mathrm{C}$ reduces the productivity of corn by $8 \%$, and of soybean by only $1 \%$.

Out of the systems analyzed, combining different forms of occupation of the agricultural area for the second crop, System 3 had the highest return and the lowest probability of a negative return. System 5 had the worst economic performance (Figure 1). 
In System 3, the choice of sowing the agricultural area with $100 \%$ soybean in the summer and the entire area with corn in the second crop showed an 8 $\%$ chance of presenting a negative return. Moreover, with a combination of $80 \%$ of the agricultural area sown with soybean and $20 \%$ with corn in the summer crop, with $80 \%$ corn in the second crop, the risk of a negative return reduces to $4 \%$. In the composition of the agricultural area with $60 \%$ soybean and $40 \%$ corn in the summer crop and $60 \%$ corn in the second crop, the chance of a negative return for the farm decreases to $3 \%$. As the corn proportion increases in the agricultural area in the summer crop, the profitability of the farm and the negative return risk move up. When the corn crop occupies $60 \%$ of the agricultural area is sown with corn and the remainder with soybean, and then $40 \%$ of the area is sown with corn in the second crop, the risk of a negative return is $2 \%$. In the combination of $80 \%$ with corn and $20 \%$ with soybean in the first crop and only $20 \%$ with corn in the second crop, the result showed that the risk of a negative return rises to $4 \%$.

In System 4 with $100 \%$ of the agricultural area sown with corn in the second crop, and a combination of $80 \%$ of the area sown with soybean and the remaining $20 \%$ with corn in the summer crop, and $100 \%$ with second crop corn the risk of registering a negative return is $6 \%$. Land use in the proportion of $60 \%$ sown with soybean and $40 \%$ with corn in summer and $100 \%$ of corn in summer shows the probability of a negative return of $5 \%$. By sowing the agricultural area with more corn compared to the summer period, the risk of a negative return increases. In general, the return and the risk of the farm increase with more corn in the first crop. The difference is that the operating return of System 4 is lower than the production Systems 1 and 3, but raises risk exposure.

System 1 had superior NOR in comparison to the other four systems. When System 1 is compared to System 3 within the same combination of soybean and summer corn in first crop area, the results of System 3 were inferior. For example, comparing the same combination of $60 \%$ soybean and $40 \%$ summer corn, System 1 found an average NOR of US\$ $412.6 \mathrm{ha}^{-1}$ and Prob. NOR < 0 was $1 \%$ (CV of $40 \%$ ) against System 3 with a NOR of US\$ $391.8 \mathrm{ha}^{-1}$ and Prob. NOR $<0$ was $3 \%$ (CV\% $49 \%)$. The reduction jn the NOR of System 3 was observed after the second crop had been added, which had a negative value of US\$20.8 $\mathrm{ha}^{-1}$. Increases in the share of the second corn crop in System 3, produces a decrease in the NOR and the probability of a negative result increases. In System 4, when sowing $100 \%$ of the area with the second corn crop, the average NOR value of System 4 was US\$34.6 ha ${ }^{-1}$ lower than System 1. The difference was constant for all six types of soybean and summer corn combinations (Table 3).

The presence of wheat as a second crop option was simulated in Systems 2 and 5. System 2 combines the soybean and corn crop in the summer and corn and wheat in the second crop. When $80 \%$ of the agricultural area is sown with soybean and $20 \%$ with corn in the summer crop and $80 \%$ with corn and $20 \%$ with wheat in the second crop, the risk of a negative return is $5 \%$. When the agricultural area was sown with $60 \%$ soybean and $40 \%$ corn in the first crop and subsequently, $60 \%$ corn and $40 \%$ wheat, the possibility of a negative return is $4 \%$. Furthermore, by reducing the soybean area to $40 \%$ and expanding the corn area to $60 \%$ in the first crop and sowing the area with $40 \%$ corn and $60 \%$ wheat, the negative return increases to $5 \%$. The land use combination of $80 \%$ soybean and $20 \%$ corn in the first crop, and $20 \%$ corn and $80 \%$ wheat, increases the possibility of a negative return to $7 \%$. Finally, sowing the agricultural area with $100 \%$ corn in the first crop and 100 $\%$ wheat increases the risk of a negative return to $12 \%$.

In System 5, when $100 \%$ of the agricultural areas is sown with soybean and $100 \%$ with wheat in the second crop, the risk of a negative return is $9 \%$. When combining $80 \%$ soybean and $20 \%$ corn in the first crop and $100 \%$ wheat in the second crop, the risk of a negative return is $6 \%$. In the land-use composition with $60 \%$ soybean and $40 \%$ corn in the first crop, the risk of a negative result is $5 \%$. This risk increases as the proportion of corn increases. When the agricultural area is sown with $60 \%$ corn and $40 \%$ soybean in the first crop and the entire area with wheat in the second crop, the risk of a negative return is $6 \%$. When the land use is $80 \%$ corn and $20 \%$ soybean in the first crop and 100 $\%$ of the area is sown with wheat in the second crop, the risk is $9 \%$. The combination of the entire area being sown with corn in the first crop and wheat in the second crop, implies the risk of a negative return of $12 \%$, as observed in System 2 (Figure 1).

In the case of System 2, the combination of second corn crop and wheat presented negative NOR and the profitability of System 2 declines as the wheat area proportion increases in the production system since the NOR of wheat is more negative than a second corn crop. System 5, in which $100 \%$ of the area was sown with wheat in the second harvest, the average NOR value of System 5 was US $\$ 82.6$ ha $^{-1}$ lower than System 1 (Table 3).

In general, the results showed that the production system with soybean and corn in the first crop has a higher NOR and lower risk when compared with the other four systems, which enhances the land use with the second crop. However, when the presence of corn is increased in the first crop, at the expense of soybean, the NOR and risk also increase. The agricultural area sown with $60 \%$ soybean and $40 \%$ corn showed the lowest risk.

In the more intensive production system, which introduces a second crop after soybean or corn, the risk of the typical farm increases. In the four cases assessed, all recorded increased risk, but profitability did not outperform the one-crop cultivation system. This result raises questions about the producer's strategy for maximizing land use in an attempt to earn as much with the first as with the second crop. 
Cultivating corn and wheat in the second crop showed that both increase risk to the production system. The most worrying situation is the presence of wheat, as it considerably lowers profitability and increases risk to the production system of the farm, as seen in Systems 2 and 5. Wheat production in Brazil is more vulnerable to climate variations and the grain quality is easily reduced, which in turn decreases the producer's remuneration. On the other hand, the presence of this crop in the system is justified by its stimulation of productivity gains in soybean and corn, since this cereal increases straw in the soil, and promotes crop rotation and chemicals to control weeds, diseases and pests.

As regards second crop corn, it was expected that its introduction into the production system would increase the profitability of the farm, but this was not observed in Systems 2, 3 and 4. It is suspected that the new genetic technology introduced in the seed and the greater use of insecticides increased the cost of production, especially in the last three years $(2011 / 12$ to $2013 / 14$ ), reducing the profitability of second crop corn. Nevertheless, our study did not discriminate production by type of technology, which will be the focus of future research. Out of the four systems used in the agricultural area for two crops, System 3 showed the most promising results, particularly the composition of the agricultural application of $60 \%$ soybean, and $40 \%$ corn in the summer crop and $60 \%$ corn in the second crop.

The study was limited to assessing one location, restricting any economic risk considerations posed by the five production systems to Cascavel alone. Even so, it produced results were far-reaching, given that the primary data used to portray the reality of the production system (management and technology) of each crop, were validated by local producers and consultants and obtained over a long period.

\section{Authors' Contributions}

Conceptualization: Osaki, M., Alves, L.R.A. Data acquisition: Osaki, M., Lima, F.F., Ribeiro, R.G. Data Analysis: Osaki, M., Alves, L.R.A. Design of methodology: Osaki, M., Alves, L.R.A., Barros, G.S.A.C. Software development: Osaki, M., Alves, L.R.A. Writing and Editing: Osaki, M., Alves, L.R.A., Barros, G.S.A.C.

\section{References}

Arêdes, A.F.; Pereira, M.W.G.; Santos, V.F.; Arêdes, A. 2007. Return and price risk analisis in the production of corn, soybeans and beans in Parana state in the period from 1997 to 2006 = Análise do retorno e risco de preço na produção de milho, soja e feijão no Paraná no período de 1997 a 2006. Informações Econômicas 37: 17-22 (in Portuguese).

Asci, S.; VanSickle, J.J.; Cantliffe, D.J. 2014. Risk in investment decision making and greenhouse tomato production expansion in Florida. International Food and Agribusiness Management Review 17: 1-26.
Blank, L.; Tarquin, A. 2012. Engineering Economy. 7ed. McGrawHill, New York, NY, USA.

Centro de Estudos Avançados em Economia Aplicada [CEPEA]. 2016. Cost and Management $=$ Custo de Produção. Avaliable at: https://www.cepea.esalq.usp.br/br/gestao-do-negocioagropecuario.aspx [Accessed Oct 2, 2016] (in Portuguese).

Deblitz, C.; Isermeyer, F.; Anderson, D.; Hemme, T.; Knutson, R. 1998. The International Farm Comparison Network (IFCN): Objectives, Organisation, First Results on Dairy Production. IFC, Washington, DC, USA.

Elliott, F.F. 1928. The "Representative Firm" idea applied to research and extension in agricultural economics. Journal of Farm Economics 10: 483-498.

Feuz, D.M.; Skold, M.D. 1991. Typical farm theory in agricultural research. Journal of Sustainable Agriculture 2: 43-58. DOI:10.1300/J064v02n02_05

Hatfield, J.L.; Boote, K.J.; Kimball, B.A.; Ziska, L.H.; Izaurralde, R.C.; Ort, D.; Thomson, A.M.; Wolfe, D. 2011. Climate impacts on agriculture: implications for crop production. Agronomy Journal 103: 351-370. DOI: 10.2134/agronj2010.0303

Hazell, P.B.R.; Norton, R.D. 1986. Mathematical Programming for Economic Analysis in Agriculture. 3ed. Macmillan, London, UK.

Hertz, D.B. 1964. Risk analysis in capital investment. Harvard Business Review 42: 95-106.

Instituto de Pesquisa Econômica Aplicada [IPEA]. 2015. IpeaData: Macroeconomic = IpeaData: Macroeconômico. IGP-DI. Avaliable at: http://www.ipeadata.gov.br/Default.aspx [Accessed Jan 2, 2015] (in Portuguese).

Melo, C.O.; Silva, G.H.; Esperancicni, M.S.T. 2012. Economic analysis of corn and soybean production: summer crop in the state of Paraná, Brazil. Revista de Política Agrícola 21: 121-132 (in Portuguese, with abstract in English).

Noronha, J.F. 1987. Agricultural Projects: Financial Administration: Budget and Economic Viability $=$ Projetos Agropecuários: Administração Financeira: Orçamento e Viabilidade Econômica. Atlas, São Paulo, SP, Brazil (in Portuguese).

Osaki, M.; Batalha, M.O. 2014. Optimization model of agricultural production system in grain farms under risk, in Sorriso, Brazil. Agricultural Systems 127: 178-188. DOI:10.1016/j. agsy.2014.02.002

Plaxico, J.S.; Tweeten, L.G. 1963. Representative farms for policy and projection research. Journal of Farm Economics 45: 14581465.

Ponciano, N.J.; Souza, P.M.; Mata, H.T.C.; Vieira, J.R.; Morgado, I.F. 2004. The economic feasibility analysis and risk of fruit production in the north area of Rio de Janeiro. Revista de Economia e Sociologia Rural 42: 615-635 DOI:10.1590/S010320032004000400005 (in Portuguese, with abstract in English). 